\title{
Branding itself: an introduction
}

"Brand is everything, and everything is brand."

What do survivors of a mass shooting in Florida, Russian intelligence officers, Coca-Cola and the president of the United States all have in common? They all try to influence public opinion using branding, even if what is getting branded is the truth, a lie, a myth or a conspiracy.

\section{COMMERCIAL BRANDS}

But before we can explore all of that, we need some shared definitions. "Branding" is the process of purposefully repeating a word, concept or logo until it gets stuck in the minds of the public. ${ }^{2}$ Commercial branding comes from business entities like partnerships, limited liability companies (LLCs) and corporations. Commercial branding is ubiquitous. Nearly from the moment the average American opens her eyes in the morning to the moment she goes to sleep, branding is everywhere, from the products in her bathroom to the food in her kitchen, the vehicles in her garage, the billboards on her commute, the sign outside her workplace, the product placements on TV and the banner ads online. Brands are so omnipresent in our lives that they sometimes slip into genericide. Linguists Julie Sedivy and Greg Carlson, in their book Sold on Language, provide multiple examples of how brands have become shorthand for objects in our daily lives:

If you stroll across your linoleum floor over to your formica countertop, check on the stew in the crock-pot, pick up the spilled kitty litter in the corner with a kleenex, pour a bowl of granola, and open your freezer to take out a popsicle before proposing a game of after-dinner ping pong, you are contributing to the genericide of these brand names. ${ }^{3}$

Dan Pallotta, A Logo Is Not a Brand, Harv. Business Rev. (June 15, 2011).

2 Len Stein, The Key to Brand Design is "Deliberate Differentiation," BrandingmaG (Dec. 18, 2017), www.brandingmag.com/2017/12/18/the-key-to-brand -design-is-deliberate-differentiation/ (quoting Debbie Millman) ("'Branding is deliberate differentiation."').

3 Julie Sedivy \& Greg Carlson, Sold on Language: How Advertisers Talk to You and What This Says About You 47 (2011). 
Even as brands seep into our language, they are vulnerable to picking up negative associations and generating revulsion. As Professor Tamara Piety notes in her book Brandishing the First Amendment:

It is possible to create a brand out of whole cloth. However, because brand value is so dependent on imagery built by communication efforts, it is, to some extent, always susceptible to sudden shifts in public perceptions. Such shifts may include total collapse of all brand value. ${ }^{4}$

Or as David D’Alessandro, president of John Hancock Mutual Life Insurance, once quipped: "It can take 100 years to build up a good brand and 30 days to knock it down."5 In the Twitter age, death of a brand can happen even quicker.

Evidence of the importance of branding to corporations can be seen in the public relations and advertising budgets of firms. ${ }^{6}$ Most of the corporate money allotted for branding is spent on advertising. As a report in Fortune indicated in 2012, "US companies spend $\$ 150$ billion annually on advertising and only $\$ 5$ billion on public relations." $"$ By 2018, advertising in the U.S. hit the $\$ 166$ billion mark ( $\$ 107$ billion of it on digital ads). ${ }^{8}$ Worldwide spending on advertising in 2018 was $\$ 414$ billion (\$227 billion of it online). ${ }^{9}$

And some brands exist on a societal level. Think about the ubiquitous "Santa Claus" brand. When I had my son, my husband and I resolved not to lie to him about the existence of Santa Claus. I thought this would be easy. How little did I appreciate the media environment that he would inhabit from age zero to five. First, there were other caregivers in his life-from grandparents to nursery school teachers - who told him Santa was real. Then there were ubiquitous ads on TV, radio and billboards in which Old Saint Nick sold everything from Coke to M\&Ms to Norelco shavers. There was the "mall Santa," with long

4 Tamara R. Piety, Brandishing the First Amendment: Commercial Expression IN AMERICA 33 (2013).

5 Naomi Klein, No Logo: Taking Aim at the Brand Bullies 345 (1999).

6 See Strategic Commc'n \& Pub. Relations Ctr., Univ. S. Cal. Annenberg Sch. of Commc'n \& Journalism, GAP VII: Seventh Communication and Public Relations Generally Accepted Practices Study (Q4 2011 Data) 15 (2012), http:// ascjweb.org/gapstudy/wp-content/uploads/2014/06/GAP-VIII-Presentation-Final-6.12 .2014.pdf. 2012).

Gregory Galant, Why Public Relations Gets No Respect, Fortune (Nov. 15,

8 Dana Feldman, U.S. TV Ad Spend Drops As Digital Ad Spend Climbs To $\$ 107 B$ In 2018, Forbes (Mar. 28, 2018).

9 Rani Molla, Advertisers will spend $\$ 40$ billion more on internet ads than on TV ads this year Thank social, video and mobile., RECODE (Mar. 26, 2018), www.recode .net/2018/3/26/17163852/online-internet-advertisers-outspend-tv-ads-advertisers -social-video-mobile-40-billion-2018. 
lines of children waiting to sit on his lap and tell him their desires. There were men on Christmas pub crawls through Brooklyn dressed in red suits and fake white beards. But the real nail in the coffin for our battle with this branded lie was PBS. My young son saw Santa show up in most of his children's shows, from Bob the Builder to Thomas the Tank Engine. And for him, that made Santa real - at least when he was very young. I could not have been prouder when, as a five-year-old, he said to me and my husband, "Wait, this Santa thing doesn't add up." And we said, "You're right. It doesn't." The spell was broken.

The word "brand" comes from the Old English word "brond," meaning "fire," 10 which in turn came from the Norse word "brandr," which meant "burn." 11 Branding's historical roots derive from farmers using a red-hot iron to sear an image, like the initials of the owner or a family crest, into the flesh of livestock. This type of "branding" was a way of telling Farmer Joe's cows from Farmer Steve's cows. The practice of branding cattle goes back thousands of years. According to the Smithsonian, branding dates back to at least 2700 $\mathrm{BC}$, where there is evidence of livestock branding depicted in ancient Egyptian hieroglyphics. ${ }^{12}$ By the 1500s, "brand" in English referred "to a mark burned on cattle to show ownership." "13 In the American context, branding cows was important at the slaughterhouse, where payment to the source farms could depend on how many animals bearing a particular "brand" were slaughtered. ${ }^{14}$

Trademarks on hand-crafted goods have a parallel history to agricultural branding. In Europe, during the Middle Ages, craft guilds would stamp craftworks with marks of both the artisan and the guild. ${ }^{15}$ The guild mark alerted customers that the creation was up to the guild's high standards. ${ }^{16}$ Modern trademarks can serve a similar purpose: think of an $\mathrm{ABA}^{\mathrm{TM}}$ (American Bar

10 Online Etymology Dictionary, Branding, www.etymonline.com/index.php?term =brand ("brand (n.) Old English brand, brond "fire, flame ..."”).

11 Matt Shadel, A Brief History of Branding, Convoy (Jan. 8, 2014), www .weareconvoy.com/2014/01/a-brief-history-of-branding/ ("The modern word Brand is derived from the word 'Brandr', a word from Ancient Norse meaning 'to burn ...'”).

12 Jimmy Stamp, Decoding the Range: The Secret Language of Cattle Branding, SMithsonian (Apr. 30, 2013).

13 Shadel, supra note 11.

14 Jerry McLaughlin, What is a brand, anyway?, Forbes (Dec. 21, 2011) (“As the cattle moved across the plains on their way to Chicago slaughter houses, it was easy to determine which ranches they were from because each head of cattle was branded.").

15 Thomas D. Drescher, The Transformation and Evolution or Trademarks-from Signals to Symbols to Myth, 82 Trademark ReP. 301, 314 (1992) ("In the 1300s, master craftsmen in a guild had to choose a mark specific to their work which would be affixed to their products.").

$16 I d$. at 316 (crafts usually bore a second mark as well, which represented the collective mark of the guild. This mark certified the craft met the regulations and criteria of that guild.). 
Association) approved law school. $\mathrm{ABA}^{\mathrm{TM}}$ accreditation tells the public that that particular school has met the guild's high standards.

The meaning of "branding" has certainly evolved beyond marking livestock with hot irons. According to Mustafa Kurtuldu, "[t]he transition from 'This belongs to me, so leave it ...' to 'This was made by me, so buy it' started to evolve in the 1800's." ${ }^{17}$ Commercial branding as Americans know the practice today took off as corporations tried to market what had been previously undistinguishable dry goods, like fungible piles of oats or beans. ${ }^{18}$ The "brand" told the customer which corporation was the source of a particular box of oats or can of beans. While it may not have mattered to the average farmwife shopping at a dry goods store on the prairie in the 1800s whether she bought Quaker Oats or Heinz Beans, it mattered a great deal to the Quaker and Heinz corporations, which spent handsomely to advertise the high quality of their oats, beans or whatever else they were selling, so that shoppers around the nation would buy these brands over similar quality, but unadvertised or generic alternatives. ${ }^{19}$

The need for branding is most acute when the market is flooded with nearly indistinguishable and fungible goods. As Forbes once explained of Coke:

In the late 1880 s, for example, as the Coca-Cola Company was getting started, there were many soda producers in every market. Before Coca-Cola could get a customer to reach for a Coke, it needed to be sure the customer could distinguish a Coke from all the other fizzy caramel-colored beverages out there ... A Coke is a fizzy caramel-colored soda concocted by those folks in Atlanta. ${ }^{20}$

Coca-Cola was started as patent medicine that was advertised as "an ideal nerve tonic," which contained wine and cocaine. After a local temperance law passed, later formulations of Coke changed to sugar and cocaine. Then finally Coca-Cola went with its modern formula of just sugar and caffeine. ${ }^{21}$ In the 1800 s, patent medicines were heavily advertised, including strange tinctures which claimed to be miracle cures for exhaustion and headaches. Often the main active ingredient was cocaine, just like the original Coca-Cola. ${ }^{22}$ But the corporations making the patent medicines wanted consumers to buy their cocaine, not the other guy's cocaine.

17 Mustafa Kurtuldu, Brand New: The History of Branding, Design Today (Nov. 29, 2012), www.designtoday.info/brand-new-the-history-of-branding/.

18 Drescher, supra note 15 at 321 (up until the post-Civil War period, many commodities were fungible.).

19 Id. at 323 (Quaker Oats was not started by a Quaker.).

20 McLaughlin, supra note 14.

21 James Hamblin, Why We Took Cocaine Out of Soda, Atlantic (Jan. 31, 2013).

22 Kurtuldu, supra note 17. 
And this process continues today, as firms try to distinguish their company's cookie-cutter SUV, sedan or pick-up truck from another company's cookie-cutter SUV, sedan or pick-up truck merely with a hood ornament or a name on the bumper. For instance, what love and a hatchback station wagon have to do with each other is a mystery to me, but years of ads have told millions of consumers that "love is what makes a Subaru a Subaru." 23

Typically, building up positive connotations for a brand is done through advertising using standard puffery. ${ }^{24}$ Old standbys for advertisers are the assertion (true or not) that if the customer buys this product, she will be more powerful, rich, intelligent, sexy, envied or successful. ${ }^{25}$ But the lies to sell products can get out of hand, as Vance Packard complained in his book The Waste Makers: "Millions of consumers are manipulated, razzle-dazzled, indoctrinated, mood-conditioned, and flimflammed."26

Jingles to sell products are often "earworms" that get stuck in viewers' heads. They can be so insidious that even if viewers hate the product or the company behind it, the ad copy is stuck in their minds. As Drew Westen notes, " $[\mathrm{w}]$ hen even people who don't like your product are humming your jingle, you know you've got them where it counts: in their [neural] networks." ${ }^{27}$ Likewise, ad man Nigel Hollis once wrote:

engaging and memorable ads slip ideas past our defenses and seed memories that influence our behavior. You may not think advertising influences you. But marketers do. And in addition to millions of dollars, they have something else most people don't have: Access to data that proves their point. ${ }^{28}$

23 Diana T. Kurylko, How Subaru marketing found the 'Love', Auto NEws (Feb. 12, 2018), www.autonews.com/article/20180212/RETAIL03/180219982/how-subaru -marketing-found-the-love.

24 Raymond Perrier, Valuation Issues: The Value of a Brand as a Financial Asset, Corp. Fin. Rev. (March/April 1998).

25 Deven R. Desai, From Trademarks to Brands, 64 Fla. L. Rev. 981, 990-91 (2012) ("Many companies encourage consumers to see a brand as having a personality and to accept the idea that owning a branded good connects the consumer to the brand in some deep, personal way. ... Taken further, a consumer may use a brand to express herself.") (internal citations omitted).

26 Vance Packard, The Waste Makers 250 (1960 reprinted 1971).

27 Drew Westen, The Political Brain: The Role of Emotion in Deciding the FAte of the Nation 165 (2007).

28 Nigel Hollis, Why Good Advertising Works (Even When You Think It Doesn't), Atlantic (Aug. 31, 2011). 
As the data crunchers over at Nielsen have found, "[p]ractice (repetition) indeed makes perfect - and can help create durable memories." ${ }^{29}$ One of the oddities of advertising brands is that some customers associate repetitive ads with higher-quality products. Objectively, this is somewhat absurd, since a heavily advertised item could be poorly constructed, carcinogenic or addictive. But nonetheless, this is a measurable phenomenon:

Repetition of an ad may signal to consumers that the brand or product is a good buy, or a quality product. This is sometimes referred to as signaling theory. In 1975, University of Wyoming researchers Anthony McGann and Raymond Marquardt found that ads with high rates of repetition tended to also be rated as high quality in Consumer Reports. ${ }^{30}$

And even more disturbingly, the more an ad is repeated, the more viewers will believe it (even if the claim that is being repeated is not true). "Studies suggest that repeated statements are perceived as more truthful than statements made less frequently, 'presumably because repetition imbues the statement with familiarity.' In simple terms: frequency breeds familiarity, and familiarity breed trust." 31

A well-established brand enables the brand owner to charge a premium over a competing similar generic product or service. ${ }^{32}$ Thus, the economic meaning of a "brand" is that value-added quality of a product that convinces a customer

29 David Brandt, Understanding Memory in Advertising, Nielsen (Feb. 22, 2017), www.nielsen.com/us/en/insights/journal-of-measurement/volume-1-issue -3/understanding-memory-in-advertising.html; Sean H. K. Kang, Spaced Repetition Promotes Efficient and Effective Learning: Policy Implications for Instruction, 3 Behavioral and Brain Sciences 12 (2016) ("Massed repetition eliminates the retrieval process - there is no need to retrieve from memory because the same item was just presented.").

${ }_{30}$ Lisa Magloff, Repetition as an Advertisement Technique, CHRON (Feb. 1, 2019), https://smallbusiness.chron.com/repetition-advertisement-technique-24437.html.

31 Jeffry Pilcher, Say It Again: Messages Are More Effective When Repeated, FinANCIAL BRAND (Sept. 23, 2014), https://thefinancialbrand.com/42323/advertising -marketing-messages-effective-frequency/; see also Linda Henkel \& Mark Mattson, Reading is believing: the truth effect and source credibility, 20(4) Conscious Cogn. 1705-21 (Dec. 2011) ("familiarity may create an illusion of truth for statements when people lack source-specifying cues, especially cues regarding the reliability of the source.").

32 Mark Fenster, Coolhunting the Law, 12 Harv. Negot. L. Rev. 157, 161 (2007) ("A successful brand will both command a high premium and control significant market share. In this way, successful brands offer 'brand equity,' an intangible asset with a fuzzily measurable value that can, in some instances, represent a significant portion of a corporation's overall value.") (internal citations omitted); Marc De Swaan Arons, How Brands Were Born, Atlantic (Oct. 3, 2011). 
to pay more than he would pay for a similar generic product because of a positive association with the source of the product. ${ }^{33}$ Thus, a customer might pay 50 percent more for a white J.Crew t-shirt because it is a J.Crew t-shirt, even though objectively it is no different than a no-name white t-shirt. ${ }^{34}$

The largest publicly traded companies are sometimes richer than nations. ${ }^{35}$ They are big, global and imposing, but they have two Achilles' heels related to their brands: rejection by their investors and shunning by their customers. ${ }^{36}$ If the brand is damaged, the company is likely to suffer. ${ }^{37}$ Corporations typically want to add to the value of their brands, not detract from it. ${ }^{38}$ The goodwill ${ }^{39}$ associated with a brand may well be a company's greatest asset. ${ }^{40}$ Indeed, intellectual property litigation is often launched by firms to ensure that no one is using a copyrighted brand logo, trade dress or trademark in a way that

33 The Lemon Dilemma, The Economist (Oct. 11, 2001), www.economist.com/ node/813705 ("[B]rands do help to make the world easier to navigate. A Coke or a Big Mac, say, is almost the same everywhere in the world. The customer knows the quality of a product by its brand.").

34 See Jeremy N. Sheff, Biasing Brands, 32 Cardozo L. Rev. 1245, 1260 (2011).

35 See Vincent Trivett, 25 US Mega Corporations: Where They Rank If They

Were Countries, Business InsIDER (June 27, 2011), www.businessinsider.com/ 25-corporations-bigger-tan-countries-2011-6.

36 KLEIN, supra note 5, at 334 ("Brand image, the source of so much corporate wealth, is also, it turns out, the corporate Achilles' heel.").

37 See Mario Biagioli, Anupam Chander \& Madhavi Sunder, Brand New World: Distinguishing Oneself in the Global Flow, 47 U.C. Davis L. REv. 455, 465-66 (2013) ("Corporations now invest time and resources into leading the consumers to associate a certain brand with a certain image ...").

38 See Tim Minahan, Risk Management Lessons From Toyota, Forbes (May 10, 2010) ("Your brand is a set of perceptions and images that represent a company or product.").

39 See Newark Morning Ledger Co. v. United States, 507 U.S. 546, 555-56 (1993) ("Although the definition of goodwill has taken different forms over the years, the shorthand description of good-will as 'the expectancy of continued patronage,' Boe $v$. Commissioner, 307 F.2d 339, 343 (9th Cir. 1962), provides a useful label with which to identify the total of all the imponderable qualities that attract customers to the business." (citing Hous. Chronicle Publ'g Co. v. United States, 481 F.2d 1240, 1248 n.5 (5th Cir. 1973))).

40 See Jan Lindemann, Brand Valuation, in Brands and Branding, An Economist Book 1, 27 (Rita Simmons, et al., eds., 2004) ("If this business were split up, I would give you the land and bricks and mortar, and I would take the brands and trade marks, and I would fare better than you."); Jerre B. Swann \& Theodore H. Davis, Jr., Dilution, An Idea Whose Time Has Gone; Brand Equity as Protectable Property, The New/Old Paradigm, 1 J. Intell. Prop. L. 219, 229 (1994) ("As is evident from the merger mania of the 1980's, brands are often more valuable [than] the physical assets of a business."). 
would tarnish or harm a brand ${ }^{41}$ As Justice Frankfurter once held: "The protection of trade-marks is the law's recognition of the psychological function of symbols." 42 And the value of these symbols can reach the billions. Forbes estimated the value of Nike's swoosh at \$26 billion; ${ }^{43}$ though that pales in comparison to Apple's "apple with a missing bite" brand, which Forbes valued at $\$ 170$ billion. $^{44}$

Typically, because they want to be able to charge a premium, most owners of commercial brands try to steer clear of negative connotations. There are, of course, a few brands that like to flirt with a more edgy image as a way to cut through the clutter and enter the public consciousness. Think of Red Bull's sponsorship of dangerous sporting events and stunts, some of which have turned deadly. ${ }^{45}$ Here, being a "renegade" is part of building the brand. If branding is in part a battle to grab the audience's attention, then being "extreme" can actually be helpful in building a brand.

But edgy brands walk a delicate line. If the "extreme" brand or the "extreme" brand ambassador gets in real trouble socially or legally, then the company behind the brand can suffer. For instance, before it went bankrupt in 2017, ${ }^{46}$ American Apparel had ads with models wearing nothing but socks or legwarmers, or in other states of undress. ${ }^{47}$ The sexualized image seemed to help sell the brand, which lasted 19 years. American Apparel's founder, Dov Charney, seemed to revel in the controversy over the sexy ads, which won

41 See Lauren Behr, Trademarks for the Cure: Why Nonprofits Need Their Own Set of Trademark Rules, 54 B.C. L. Rev. 243, 256 (2013) ("[The 1996 Federal Trademark Dilution Act ("FTDA")] established a federal cause of action against use that could tarnish or devalue a senior user's mark.").

42 Mishawaka Rubber \& Woolen Mfg. Co. v. S.S. Kresge Co., 316 U.S. 203, 205 (1942).

43 Mike Ozanian, The Forbes Fab 40: The World's Most Valuable Sports Brands 2015, Forbes (Oct. 22, 2015), www.forbes.com/sites/mikeozanian/2015/10/22/the -forbes-fab-40-the-most-valuable-brands-in-sports-2015/\#6b79a5df1752.

${ }_{44}$ Kurt Badenhausen, Apple Heads The World's Most Valuable Brands of 2017 at $\$ 170$ Billion, Forbes (May 23, 2017).

45 Tom Porter, Red Bull Under Fire Over Seventh Death at Tyrol Stunt Event, INT'L Bus. Times (May 5, 2013).

46 Bankrupt Retailer American Apparel Begins Laying Off Thousands of Workers, Reuters (Jan. 16, 2017).

47 American Apparel Adverts Banned: 'Sexual And Objectifying' Images Show Models Half Naked, HufF. Post (Oct. 4, 2013). 
the brand earned media ${ }^{48}$ - right up until the point his board ousted him after a series of sexual harassment lawsuits were filed against him. ${ }^{49}$

Even spokespersons can hurt brands if they get into enough trouble. For example, when Tiger Woods was suspected of cheating on his wife, many brands that he had endorsed dropped him as a spokesperson. ${ }^{50}$ And when Michael Vick got in criminal trouble for dog fighting, brands similarly shunned him. ${ }^{51}$ As reported in Advertising Age, "[w]hen you hang a brand on one guy, you're taking a huge risk." 52

Some companies will even rebrand if the old brand has picked up too many negative connotations. In an episode of The Simpsons, there is the following colloquy:

Kent Brockman from the TV: In response to the outcry, Lard Lad's parent company, Tianjin Mining and Smelting and Donuts, has issued the following statement: "We are rebranding Lard Lad with an updated statue."

Homer: Ooh, rebranding!

Lisa: That just means admitting failure, Dad.

Homer: Ooh, admitting failure! $!^{53}$

And indeed, rebranding is typically an admission that the previous brand has failed. An example of this phenomenon is when a mobile payment system called "Isis" decided to rebrand itself as "Softcard" in 2014 because of the possible negative connotation associated with the terrorist group ISIS. ${ }^{54}$ The companies involved in the Isis mobile payment project included AT\&T, Verizon and T-Mobile, which decided that despite the price of rebranding, it

48 Hannah Marriott, Dov Charney: the man who put the sleaze factor into American Apparel, Guardian (June 19, 2014).

49 Frank Bruni, A Grope and a Shrug Dov Charney, American Apparel and Sexual Harassment, N.Y. Times (June 30, 2014).

50 Geoffrey Norman, Can You Forgive Him?, 18 Weekly Standard 26 (2013) ("After the scandal, he [Tiger Woods] lost almost all of his high profile endorsements. ... One study estimated shareholder losses from the damage to brands caused by the scandal at between $\$ 5$ billion and $\$ 12$ billion.").

51 Emily B. York, Phelps Brand Takes a Hit, 80 Advertising Age 24, 27 (2009) ("Few brands want a puppy-killing, dogfight-organizing felon. Powerade, Airtran, Hasbro all walked away [from Vick]. So did Nike when the verdict came in.").

52 Jeremy Mullman, Reducing Risk of Vick-timization, 78 AdVertising Age 27 (2007) (quoting Jason Cavnar).

${ }^{53}$ The Simpsons Season 28, Episode 1, Monty Burns' Fleeing Circus, Wikiquote, https://en.wikiquote.org/wiki/The_Simpsons/Season_28.

54 See Press Release, Michael Abbot, CEO, ISIS Plans to Rebrand According to CEO, Green SheEt (July 7, 2014). 
would be less costly than keeping a tainted brand. ${ }^{55}$ Similarly, after the negative addictive and carcinogenic qualities of tobacco became undeniable, Philip Morris (a famous tobacco company) changed its name to Altria in 2003. ${ }^{56}$ After a Mother Jones exposé of the Corrections Corporation of America, it changed its name to Core Civic. ${ }^{57}$ Likewise, Erik Prince's private contractor firm Blackwater has rebranded itself twice after it killed 17 civilians in Iraq in $2007^{58}$ - first to Xe and then to Academi. ${ }^{59}$

But one of the reasons why corporations care enough about their brand to rebrand is branding has power. The most effective branding can get into our heads so deeply that it warps how we see ourselves. As Amanda Hess observed: "now branding has taken over not just work but life itself, seizing control of our appearances, our social relationships, even our approach to civil society." 60 Put another way, "[b]rands allow businesses to reach consumers directly with messages regarding emotion, identity, and self-worth. ..."61 Branding often plays on our emotions and tries to fill deep psychological needs like wanting to accepted. ${ }^{62}$

Ads - whether they are advertising a product or a candidate - are trying to shape our impression of what's for sale and whether we want that in our lives.

\footnotetext{
55 Stephen T. Watson, Isis? ISIS? Similarity Causes Change in Branding, Buffalo News (Oct. 6, 2014).

56 Elizabeth A. Smith \& Ruth E. Malone, Altria Means Tobacco: Philip Morris's Identity Crisis, 93(4) Am. J. Public Health 553-56 (Apr. 2003),

www.ncbi.nlm.nih.gov/pmc/articles/PMC1447789/.

57 Shane Bauer, A Stray Email Exposes a Prison Company's Rebranding Efforts. CoreCivic enlists help from a PR firm that boasts an "aggressive media strategy" for countering journalists., MOTHER JONES (Jan. 19, 2017), www.motherjones.com/ politics/2017/01/corecivic-cca-private-prison-pr-firm-hillenby/.

58 Nathan Hodge, Accused Blackwater Shooters Turning Themselves In, WIRED (Dec. 8, 2008).

59 Nathan Hodge, Company Once Known as Blackwater Ditches Xe for Yet Another New Name, Wall St. J. (Dec. 12, 2011).

${ }_{60}$ Amanda Hess, What Happens When People and Companies Are Both Just 'Brands'?, N.Y. Times Mag. (May 1, 2018).

${ }_{61}$ Deven R. Desai \& Spencer Waller, Brands, Competition, and the Law, 2010 B.Y.U. L. REV. 1425, 1427 (2010).

62 Vance Packard, The Hidden Persuaders 47 (1957 Reprinted 1969) (“'Basically, what you are trying to do,' [Pierre Martineau] advised, 'is create an illogical situation. You want the customer to fall in love with your product and have a profound brand loyalty when actually content may be very similar to hundreds of competing brands.' To create this illogical loyalty, he said, the first task 'is one of creating some differentiation in the mind - some individualization for the product which has a long list of competitors very close to it in content."').
} 
To get into our brains, being the first to make a first impression matters. As Drew Westen put it:

We have known for half a century that in advertising, being the first to make a pitch renders an effort at persuasion more effective. The one who gets there first has the widest latitude in shaping [neural] networks while they are most malleable (i.e., when no other dots have been firmly connected. $)^{63}$

One way to get there "first" is to hit customers while they are still children, when their minds still have plasticity. Targeting children is important for advertisers because "[w]e do the overwhelming majority of our learning when we are children. By the time we are seven, most of our mental highways have been constructed." ${ }^{64}$ If an advertiser can't get to us as children, it will try to get to us as adults through our emotions, ${ }^{65}$ since:

emotion continues to provide us with new imprints throughout our lives. ... [For instance,] Americans alive today can vividly relive the experience of watching the World Trade Center towers fall. This is because these experiences are so emotionally powerful that they are effectively seared onto our brains. ${ }^{66}$

\section{POLITICAL BRANDS}

The language of marketing has infected political discourse. Recall when President George W. Bush's Chief of Staff Andrew Card once said, "You don't introduce new products in August," explaining why the administration didn't try to "sell" the second Gulf War to the American public during the summer of $2002 .{ }^{67}$ Or as pollster Celinda Lake explained, "whether you're Pepsi or Obama you have to run a campaign to get your brand out."68

Political branding comes from the government and from political actors such as candidates, political action committees (PACs), 527s, politically active

\footnotetext{
63 Westen, supra note 27, at 346.

64 Clotaire Rapaille, The Culture Code: An Ingenious Way to Understand Why People Around the World Live and Buy as They Do 17 (2007).

65 Packard, The Hidden Persuaders supra note 62, at 219 (quoting Richard Worthington) ("People must be controlled by manipulating their [instincts and emotions] rather than by changing their reasonings. This is a fact of which politicians have always made use when they have persuaded their constituents by appealing to their sentiments, rather than by employing [reasoning], which would never be listened to or at least never prove effective for moving the crowds.").

66 RAPAILLE, supra note 64, at 17.

${ }_{67}$ Elisabeth Bumiller, Traces of Terror: The Strategy; Bush Aides Set Strategy to Sell Policy on Iraq., N.Y. Times (Sept. 7, 2002).

${ }_{68}$ Interview with Celinda Lake (Sept. 7, 2018).
} 
non-profits and political parties. When the branding comes from the government, it can be anything from useful public information-like what constitutes a balanced diet based on the best available scientific knowledge, as visualized in the U.S. Department of Agriculture's food pyramid - to actual government propaganda, like lying about what happened at the Gulf of Tonkin.

Branding from the government is propaganda when it feeds the public a particular view that is deeply misleading. Of course, the word "propaganda" carries with it a century of negative connotations. ${ }^{69}$ Though interestingly, even the word "propaganda" started with different connotations than what it has now. The word was coined by the Vatican in 1622. The original idea from Pope Gregory XV was to propagate the Christian faith in the New World through "propaganda." ${ }^{70}$ Only many centuries later, after the First World War, did the word "propaganda" turn into the ugly manipulative mess that it is today.

Political campaigns are one place where political branding attempts to define candidates, policies, even the state of the nation. Incumbents will try to brand the economy as outstanding and brand themselves as the cause of the nation's success. Challengers will try to brand the country as being on the wrong track and brand themselves as the catalyst for needed change. Another key to success for many vying for high office is the ability to convince disenchanted voters that the candidate can save them. This might explain the election and re-election of Franklin D. Roosevelt, who promised a nation of "forgotten men" going through its worst financial Depression a "New Deal" one of the all-time great political brands in history. ${ }^{71}$

In candidate campaigns, which often rely on broadcast ads to reach large and dispersed electorates, the first casualty is often the truth. If you think that elections are cerebral affairs decided by logic and facts, I have bad news for you: ${ }^{72}$

Two-thirds of voters' decisions to support one candidate or another could be accounted for by two simple variables: their partisan feelings and their feelings

69 Mark Crispin Miller, Introduction to Edward Bernays, Propaganda 9 (1928 reprinted 2005) ("Prior to World War One ... propaganda tended not to be the damning term we throw around today ... [Now it means] lies, half-truths, selective history or the other tricks[.]").

70 Id.

71 V.O. Key, Jr., Politics, Parties, \& Pressure Groups 187 (1964 5th ed.) ("Poor men, rich men, middle-class men, farmers, workers, all ... could identify themselves with the 'forgotten man,' and they could equally feel themselves deserving of a 'new deal' without insisting on exact definition of the "new deal' was to be.").

72 Packard, The Hidden Persuaders supra note 62, at 221 ("Dr. Samuel A. Stouffer, director of the Laboratory of Social Relations, Harvard University... [said] it was a good working rule that people's attitudes are more easily reached through their emotions than through their intellects."). 
towards the candidates. Candidates' positions on the issues had only a modest effect on their electoral preferences. ${ }^{73}$

Put another way, depressingly, facts frequently have nothing to do with who is electable. As Joe McGinniss summed up in his book The Selling of the President, "Politics, in a sense, has always been a con game." 74

Often what political ads play on is not the argument that we should support a particular new candidate, but rather that we (the viewer) already support the candidate because the candidate is on our team or in our tribe. As cognitive scientists show, evoking a "team" is a powerful motivator. A recent study showed that "once a group is marked as competitive, Schadenfreude [taking pleasure in the misfortune of others] and Glückschmerz [sorrow felt at the good fortune of others] follow: no learning is required." 75 For some of us, triggering the hatred of another person from another team or love of our team is nearly automatic with the right prompt.

Branding played a crucial role in the 2016 election. As Trump's ex-personal lawyer, Michael Cohen, testified before Congress on February 27, 2019:

Donald Trump is a man who ran for office to make his brand great, not to make our country great. He had no desire or intention to lead this nation - only to market himself and to build his wealth and power. Mr. Trump would often say, this campaign was going to be the "greatest infomercial in political history." He never expected to win the primary. He never expected to win the general election. The campaign - for him - was always a marketing opportunity. ${ }^{76}$

Branding has surely taken center stage with the Trump Presidency. Trump's repetitive rhetoric can leave the impression that he has a limited vocabulary. But as a master brander, he knows that repetition of catchphrases or an image is the way to hammer a point home. He's not the only one who can deploy this technique. The day after Trump was inaugurated, a Women's March in Washington, D.C. to protest him attracted more attendees than his inauguration. One way the two crowds could be distinguished at a distance was that many in the Trump crowd wore red "Make America Great Again" hats and

Westen, supra note 27, at 119.

Joe McGinniss, The Selling of the President 1968 at 26 (1969).

75 Mina Cikara, Intergroup Schadenfreude: motivating participation in collective violence, 3 Current Opinion in Behavioral Sciences 12-17 at 14 (2015).

76 Full Transcript: Michael Cohen's Opening Statement to Congress, N.Y. Times (Feb. 27, 2019). 
many in the Women's March crowd wore distinctive knitted pink hats. ${ }^{77}$ Thus, even the resistance is branded.

Branding techniques do not have to be used for an iniquitous telos. For example, branding techniques were used by Sesame Street to teach generations of children to read. ${ }^{78}$ In 1969:

John W. Macy, Jr. wrote an investigation of how public broadcasting might better serve American viewers. 'This program [Sesame Street] is directed at teaching pre-schoolers letters of the alphabet and numbers by using the commercial advertising techniques of animation, jingles, and so forth,' he wrote. ${ }^{79}$

And there is some discussion of positive uses of branding in this book, like those deployed by survivors of the Parkland massacre. But most of the book is focused on when branding is used to manipulate and abuse the public, often for base political ends.

The results of the 2016 presidential election motivated me to write this book. How, I wondered, could America have elected a brand as president? The other occurrence that motivated me to write this book is a sense that Americans are suffering from "truth decay." 80 To me, electing a brand president and the decay of truth are intertwined, because the more that voters rely on flashy branding to dictate who is electable, the more they are likely to fall for a slick, media-savvy candidate over a competent and truthful one.

I am a campaign finance lawyer by training. And one of the drivers of the high price of political campaigns is the exorbitant cost of advertising. What first got me interested in branding was a statement from Senator Russ Feingold, who warned in 2011 that political spending by companies may cause

77 Design legend Debbie Millman on branding, illustration and podcasting, BREED (May 16, 2018), https://breedlondon.com/debbie-millman/.

78 Joan Ganz Cooney, The Potential Uses of Television in Preschool Education: a report to the Carnegie Corporation of New York 10(1966), www.joanganzcooneycenter .org/wp-content/uploads/2014/01/JGC_1966_report.pdf ("If we accept the premise that commercials are effective teachers, it is important to be aware of their characteristics, the most obvious being frequent repetition, clever visual presentation, brevity and clarity ... unfortunately for our children, many teachers may have forgotten what Madison Avenue, with consummate skill, had cribbed from them.").

79 Erin Blakemore, Sesame Street's Controversial Early Years, JSTOR DAILY (Apr. 7, 2017), https://daily.jstor.org/sesame-streets-controversial-early-years/.

80 Jennifer Kavanagh \& Michael D. Rich, Truth Decay: An Initial Exploration of the Diminishing Role of Facts and Analysis in American Public Life, RAND CoRP. (2018) ("Over the past several decades, the opposite trend has emerged: an erosion of trust in and reliance on objective facts in political debate and civil discourse about public policy.”). 
the public to view them through a limited partisan lens. ${ }^{81}$ As Senator Feingold put it, "We're going to have Republican and Democrat toothpaste." quote inspired me to look at commercial branding, political advertising and how these two spheres intersect. ${ }^{83}$ And that was all before Trump was elected president.

The criminal and congressional investigations into Trump's election in 2016 have provided a treasure trove of information for a researcher like me. In a typical election, political ads that were placed on Facebook for a millisecond could be lost to history. But now some of those ads, because they are suspected to be part of a foreign attack on the integrity of our elections, are part of a permanent and public Congressional record. Like the Congressional investigation into Watergate, which gave the public a rare peek behind the curtain into the 1972 election, the investigations into the 2016 election provide a chance for a deeper dive on how modern elections are transforming.

A final reason that I wanted to write this book is to show the artifice of political branding. Typically, the people using political branding techniques are just trying to manipulate the public. When President Trump calls his Mar-a-Lago golf club in Florida the "Winter White House," that is branding-and not original branding either. President Nixon (1969-74) called his Florida home the "Winter White House" as well. ${ }^{84}$ When Special Counsel Robert S. Mueller III's investigation into the 2016 election is called a "witch hunt" by Presidential Advisor Kellyanne Conway, that is branding. ${ }^{85}$ Again, it's not original branding. As far back as the 1930 s, a search for communists among university pro-

81 The UpTake, Progressive Toothpaste to Fight Corporate Political Control, YouTube (June 16, 2011), www.youtube.com/watch?v=isg3sMKwZ1o.

82 Thomas L. Friedman \& Michael Mandelbaum, That Used to Be Us: How America Fell Behind in the World It Invented and We can Come Back 245 (2011) (quoting Senator Feingold).

83 Ciara Torres-Spelliscy, Shooting Your Brand in the Foot: What Citizens United Invites, 68 RutGers U. L. Rev. 1295 (Spring 2016).

${ }_{84}$ Bootie Cosgrove-Mather, Nixon's Winter White House Razed, CBS (July 24, 2003), www.cbsnews.com/news/nixons-winter-white-house-razed/ ("Former President Nixon's private sanctuary, known as the Winter White House, was razed. ...").

${ }_{85}$ Pamela Engel \& Natasha Bertrand, Kellyanne Conway just escalated the White House's campaign against Robert Mueller (July 21, 2017), www.businessinsider .com/kellyanne-conway-robert-mueller-trump-2017-7; John Wagner, Trump Attacks Mueller Probe for Fourth Straight Morning, Asks if it will "Go on Forever, " Wash. Post (Nov. 29, 2018); John W. Schoen, Trump Is Tweeting "Witch Hunt" A Lot More Than He Used To, as Mueller Probe Grinds On and Manafort Goes on Trial, CNBC (Aug. 1, 2018), www. cnbc.com/2018/08/01/trumps-witch-hunttweets-are-getting -more-frequent-as-mueller-probe.html. 
fessors was called a "witch hunt." 86 This phrase also harkens back to the dark days of the Salem witch trials - the original American "witch hunt." White House Chief Strategist Steve Bannon said, "drain the swamp," about limiting the power of Washington insiders, that was branding. Again, it wasn't original; it went back to President Ronald Reagan, among others. ${ }^{88}$ Senator Richard Neuberger also used the phrase "drain the swamp" in a piece in the New York Times urging the adoption of public financing for federal elections back in $1956 .{ }^{89}$ The original Mother Jones (the woman whom the magazine is named after) also said "drain the swamp" in 1913. ${ }^{90}$ Even Speaker of the House Nancy Pelosi in 2006 called for Democrats to "drain the swamp" after years of unified Republican rule under President George W. Bush. ${ }^{91}$ But when working for a firm called Cambridge Analytica, Steve Bannon tested the phrase "drain the swamp" years before it was used in the 2016 election campaign by candidate Donald Trump. ${ }^{92}$ Clearly, what Mr. Bannon was doing was brand testing, and "drain the swamp" hit the right chord for his target market. My hope is that perhaps when Americans see that "Winter White House," "witch hunt" and "drain the swamp" are all just basic branding trying to sell something, they can be less gullible about falling for messages designed to tug at our emotions

\footnotetext{
86 Ickes Assails Acts of 'Witch Hunters', N.Y. Times 13 (May 25, 1935) (“Harold L. Ickes, Secretary of the Interior, denounced 'witch hunters ..."').

87 Salem's 300 Eventful Years, N.Y. Times p. X18 (Apr. 18, 1926).

88 Ronald Reagan, Remarks to the Reagan Administration Executive Forum (Jan.
} 20, 1982), www.presidency.ucsb.edu/ws/index.php?pid=42498 ("Speaking of swamps, I want to urge you all not to get bogged down in Potomac fever. ... As the old saying goes, 'When you're up to your armpits in alligators, it's sometimes hard to remember that your original intention was to drain the swamp.'”).

${ }_{89}$ Richard L. Neuberger, Who Should Pay for Political Campaigns?, N.Y. TIMES (June 3, 1956).

90 John Kelly, What's With All Trump's Talk About "Draining the Swamp? " SLate (Oct. 26, 2016), www.slate.com/blogs/lexicon_valley/2016/10/26/why_do_trump_and his_supports_keep_talking_about_draining the_swamp.html ("Etymologist Barry Popik has traced drain the swamp back to the socialist movement of the early 20 th century.").

91 David Espo, Pelosi Says She Would Drain GOP 'Swamp,' AP (Oct. 6, 2006), www.washingtonpost.com/wp-dyn/content/article/2006/10/06/AR2006100600056 .html?noredirect=on ("Nancy Pelosi is thinking 100 hours, time enough, she says, to begin to 'drain the swamp' after more than a decade of Republican rule.").

92 Sue Halpern, Cambridge Analytica, Facebook, and the Revelations of Open Secrets, New YoRKer (Mar. 21, 2018), www.newyorker.com/news/news-desk/ cambridge-analytica-facebook-and-the-revelations-of-open-secrets ("It was in those early days of 2014, Wylie says, that he and Bannon began testing slogans like "drain the swamp" and "the deep state" and "build the wall," and found a surprising number of Americans who responded strongly to them."). 
and obfuscate the truth. ${ }^{93}$ President Trump's claim that he is "draining the swamp" is no more credible than thinking your Subaru actually loves you. But the repeated branding can put both Trump and Subaru in a more positive light, such that you may buy Trump's claims just as you might purchase a Subaru station wagon.

Let me close this introduction by noting that "branding" has been called "a process of manufacturing meaning." "I don't disagree, but that is precisely why branding's power needs to be interrogated. Manufacturing meaning is a scary power in the wrong hands. During the Third Reich in Germany, propagandist Joseph Goebbels "manufactured meaning" too. It led to genocide and a World War

Here is the structure of this book. Part I, "The Legal Landscape," will look at how the Supreme Court has set the ground rules for political discourse, especially in elections - including whether people can lie in elections, who can fund them, and how much dark money is allowed. This new legal landscape is created by a Supreme Court that has defined corruption incredibly narrowly, to the delight of dishonest politicians everywhere. Part II, "Branding Infecting Politics," will deal with the phenomenon of commercial branding techniques being utilized in political campaigns against the backdrop of America's growing partisan rift. This section will cover elections from Eisenhower to Trump. Part III, "When Branding Gets Pernicious," examines what happens when branding is used to do socially destructive things like damaging the free press, exacerbating racial tensions and undermining the integrity of a presidential election. And finally, Part IV, "Rejecting Toxic Brands," explores how citizens and customers are rejecting certain brands (or in some cases embracing others) because of their perceived political stances. Here, boycotts and other tactics are discussed. In the epilogue, I offer some policy prescriptions to address many of the problems that this book highlights along the way.

93 Robert Spero, Duping of the American Voter 166 (1980) (“The political television commercial ... is a dangerous weapon in the hands of the unscrupulous ...").

94 Stein, supra note 2. 